\title{
The Ultrastructure of Tissue Damage by Amyloid Fibrils
}

\author{
Haruki Koike*(D) and Masahisa Katsuno (D) \\ Department of Neurology, Graduate School of Medicine, Nagoya University, Nagoya 466-8550, Japan; \\ ka2no@med.nagoya-u.ac.jp \\ * Correspondence: koike-haruki@med.nagoya-u.ac.jp; Tel.: +81-52-744-2391; Fax: +81-52-744-2393
}

Citation: Koike, H.; Katsuno, M. The Ultrastructure of Tissue Damage by Amyloid Fibrils. Molecules 2021, 26, 4611. https://doi.org/10.3390/ molecules26154611

Academic Editor: Aleksandar M. Jeremic

Received: 19 July 2021

Accepted: 26 July 2021

Published: 29 July 2021

Publisher's Note: MDPI stays neutral with regard to jurisdictional claims in published maps and institutional affiliations.

Copyright: (c) 2021 by the authors. Licensee MDPI, Basel, Switzerland. This article is an open access article distributed under the terms and conditions of the Creative Commons Attribution (CC BY) license (https:/ / creativecommons.org/licenses/by/ $4.0 /)$.

\begin{abstract}
Amyloidosis is a group of diseases that includes Alzheimer's disease, prion diseases, transthyretin (ATTR) amyloidosis, and immunoglobulin light chain (AL) amyloidosis. The mechanism of organ dysfunction resulting from amyloidosis has been a topic of debate. This review focuses on the ultrastructure of tissue damage resulting from amyloid deposition and therapeutic insights based on the pathophysiology of amyloidosis. Studies of nerve biopsy or cardiac autopsy specimens from patients with ATTR and AL amyloidoses show atrophy of cells near amyloid fibril aggregates. In addition to the stress or toxicity attributable to amyloid fibrils themselves, the toxicity of non-fibrillar states of amyloidogenic proteins, particularly oligomers, may also participate in the mechanisms of tissue damage. The obscuration of the basement and cytoplasmic membranes of cells near amyloid fibrils attributable to an affinity of components constituting these membranes to those of amyloid fibrils may also play an important role in tissue damage. Possible major therapeutic strategies based on pathophysiology of amyloidosis consist of the following: (1) reducing or preventing the production of causative proteins; (2) preventing the causative proteins from participating in the process of amyloid fibril formation; and/or (3) eliminating already-deposited amyloid fibrils. As the development of novel disease-modifying therapies such as short interfering RNA, antisense oligonucleotide, and monoclonal antibodies is remarkable, early diagnosis and appropriate selection of treatment is becoming more and more important for patients with amyloidosis.
\end{abstract}

Keywords: chemotherapy; diflunisal; electron microscopy; inotersen; neurodegeneration; pathogenesis; pathology; patisiran; plasma cell dyscrasia; tafamidis

\section{Introduction}

Amyloidosis is a group of diseases in which amyloid fibrils are deposited in tissues. According to a report from the International Society of Amyloidosis nomenclature committee in 2020, 36 proteins are listed as precursors of amyloid fibrils that may be deposited in the extracellular spaces of tissues of various organs [1]. About half of these proteins are associated with localized amyloidosis, i.e., confined to a specific single organ, as is the case of Alzheimer's disease, wherein amyloid deposition occurs only in the central nervous system [1]. The other types of amyloidosis are of the systemic type, although the light and heavy chains of immunoglobulins among the proteins in these types may also cause localized amyloidosis [2]. Transthyretin (TTR) and the immunoglobulin light chain (AL) are the two major proteins that cause systemic amyloidosis, namely ATTR amyloidosis and AL amyloidosis, respectively [3]. In these diseases, amyloid deposition occurs in various organs, including the heart, lungs, liver, kidneys, gastrointestinal tract, soft tissues, and peripheral nervous system, resulting in multi-organ failure [4-6]. The mechanism of organ dysfunction resulting from amyloidosis has been a topic of debate. The restriction of ventricular wall movement resulting from massive amyloid deposition has been considered as the cause of heart failure in patients with cardiac amyloidosis $[7,8]$. Meanwhile, electron microscopic studies have demonstrated the degeneration of tissues surrounding amyloid deposits, suggesting that amyloid fibrils or non-fibrillar precursors exert deleterious effects on cells [9]. 
In this review, we describe the ultrastructure of tissue damage resulting from amyloid deposition by focusing on two major systemic amyloidoses, i.e., ATTR amyloidosis and AL amyloidosis. Because novel disease-modifying therapies for ATTR and AL amyloidoses appear one after another, therapeutic insights based on the pathophysiology of amyloidosis are also described. This article is based on previously conducted studies and does not contain any studies with human participants or animals performed by any of the authors.

\section{What Are ATTR Amyloidosis and AL Amyloidosis?}

ATTR amyloidosis and AL amyloidosis are major systemic amyloidoses that result in a fatal clinical outcome, particularly due to heart failure $[10,11]$. ATTR amyloidosis is caused by the deposition of amyloid fibrils composed of TTR, which is produced in the liver and physiologically functions as a transporter of thyroxine and retinol-binding protein [9]. This disease mainly consists of hereditary ATTR (ATTRv; v stands for variant) amyloidosis, alternatively known as familial amyloid polyneuropathy, and wildtype ATTR (ATTRwt) amyloidosis, also known as senile cardiac or systemic amyloidosis, based on the presence or absence of a mutation in TTR [6]. ATTRv amyloidosis was regarded as a disease restricted to specific areas of Portugal [12], Japan [13], and Sweden [14], while ATTRwt amyloidosis was considered a type of cardiomyopathy found in the elderly [15-17]. The advances in the diagnostic techniques and increased recognition of these diseases led to an increase in the number of newly diagnosed patients throughout the world [18]. In contrast, AL amyloidosis is caused by the deposition of amyloid fibrils composed of immunoglobulin light chains that are produced by clonal plasma or B cells [5]. AL amyloidosis may be localized due to in situ production of light chains, resulting in a benign clinical course [2]. However, systemic deposition leads to severe multiple organ dysfunction, including neuropathy, cardiomyopathy, and nephrotic syndrome [19].

Well-known textbook features of polyneuropathies resulting from ATTR and AL amyloidoses are progressive symmetrical sensory impairments collectively known as dissociated sensory loss, which is characterized by a loss of nociception and thermal sensation, as well as autonomic dysfunction such as diarrhea/constipation, orthostatic intolerance, dysuria, and erectile dysfunction, due to the loss of small-diameter nerve fibers $[4,20,21]$. These characteristics are particularly conspicuous during the early phase of neuropathy, and motor dysfunction is considered a later manifestation [11]. However, some patients, particularly those with late-onset ATTRv amyloidosis from non-endemic areas, manifest weakness and loss of all sensory modalities without clinically significant autonomic symptoms [22]. A characteristic feature of cardiomyopathy resulting from amyloidosis is heart failure with preserved ejection fraction on echocardiography $[23,24]$. Cardiac conduction abnormalities also frequently occur [4,20] (Table 1).

Table 1. Characteristics of ATTR and AL amyloidoses.

\begin{tabular}{|c|c|c|c|}
\hline & \multicolumn{2}{|c|}{ ATTR Amyloidosis } & \multirow[t]{2}{*}{ AL Amyloidosis } \\
\hline & ATTRwt Amyloidosis & ATTRv Amyloidosis & \\
\hline Precursor protein & Transthyretin & Transthyretin & $\begin{array}{l}\text { Immunoglobulin light } \\
\text { chain }\end{array}$ \\
\hline Acquired or hereditary & Acquired & Hereditary & Acquired \\
\hline Underlying condition & Aging & $\begin{array}{c}\text { Mutation in the TTR } \\
\text { gene }\end{array}$ & Plasma cell dyscrasia \\
\hline \multirow{2}{*}{$\begin{array}{l}\text { Major organ } \\
\text { involvement }\end{array}$} & Heart & Heart & Heart \\
\hline & Tendon/ligament & $\begin{array}{l}\text { Peripheral nervous } \\
\text { system } \\
\text { Gastrointestinal tract } \\
\text { Eye }\end{array}$ & $\begin{array}{l}\text { Peripheral nervous } \\
\text { system } \\
\text { Gastrointestinal tract } \\
\text { Kidney } \\
\text { Liver } \\
\text { Soft tissue }\end{array}$ \\
\hline
\end{tabular}




\section{Ultrastructure of Tissue Damage}

\subsection{Atrophy and Degeneration Induced by Amyloid Fibrils}

According to studies of autopsy specimens obtained from patients with ATTRv amyloidosis, the extent of the degeneration of neurons in the sensory and autonomic ganglia seems to be positively correlated with the amount of amyloid, suggesting that neurodegeneration occurs as a result of amyloid deposition $[4,25]$. Electron microscopy examination of nerve biopsy specimens from ATTRv amyloidosis patients demonstrated atrophy of Schwann cells opposed to amyloid fibril aggregates and loss of axons associated with these Schwann cells (Figures 1 and 2) [26-29]. The atrophy of Schwann cells near amyloid fibril masses has also been reported in specimens from AL amyloidosis patients (Figure 3) [21,30,31]. Similar findings have also been reported in the hearts of these patients [4].

The mechanisms of atrophy and subsequent degeneration of tissues near amyloid fibrils have not been fully elucidated. One of the possibilities is the stress or toxicity that is attributable to the amyloid fibrils themselves. A previous electron microscope study of nerve biopsy specimens from Portuguese ATTRv amyloidosis patients showed a long amyloid fibril penetrating the cytoplasmic membrane of a Schwann cell, suggesting direct damage of Schwann cells by amyloid fibrils [26]. In contrast, later studies did not describe this finding, but instead demonstrated distorted Schwann cells toward the direction of amyloid fibril elongation, suggesting mechanical stress resulting from traction [29]. The atrophy of Schwann cells tends to be more conspicuous in early-onset ATTRv amyloidosis patients from the conventional endemic foci in Portugal and Japan than in ATTRv amyloidosis patients from non-endemic areas [28,29]. This might be related to the size of the amyloid fibrils; the early-onset patients from the endemic foci have long and thick amyloid fibrils, whereas most patients from non-endemic areas have short and fine amyloid fibrils $[28,29,32,33]$. Mechanical stress during the process of amyloid fibril elongation may, in part, affect Schwann cells because these cells seem to be distorted toward the direction of amyloid fibril elongation (Figure 2) [29]. Similarly, autopsy specimens of the heart from early-onset ATTRv amyloidosis patients from conventional endemic foci revealed atrophy and degeneration of myocardial cells surrounded by long and thick amyloid fibrils, whereas short and fine amyloid fibrils and less conspicuous atrophy of myocardial cells were observed in patients from non-endemic areas [4].

Another possibility of the mechanisms of tissue damage is the toxicity of non-fibrillar states of amyloidogenic proteins [9,34-36]. In particular, many studies suggest the importance of oligomeric species, rather than mature amyloid fibrils, for tissue damage in Alzheimer's disease and prion diseases [34,35]. Experiments using schwannoma or neuroblastoma cell lines indeed demonstrated the toxic effects of non-fibrillar TTR, thus supporting this view [37-40]. Studies using Caenorhabditis elegans or Drosophila also demonstrated the neurotoxicity of TTR in the absence of fibrillar amyloid deposition [41]. The extent of nerve fiber loss is more conspicuous, despite the smaller number of amyloid deposits, in late-onset ATTRv amyloidosis patients from non-endemic areas than in earlyonset ATTRv amyloidosis patients from endemic foci [4], suggesting that the toxicity of non-fibrillar TTR participates in the mechanisms of neurodegeneration, especially in late-onset ATTRv amyloidosis patients from non-endemic areas. 


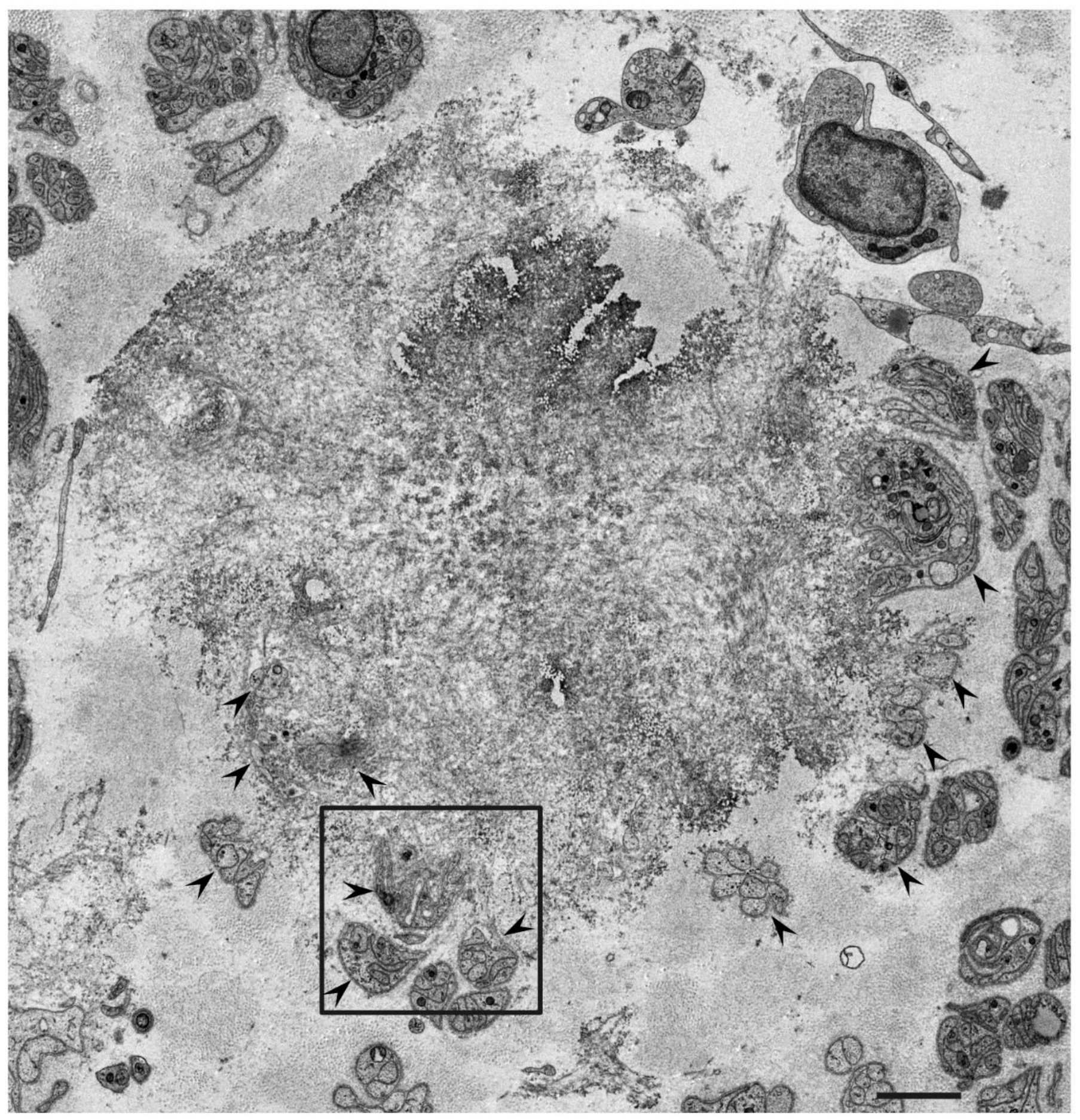

Figure 1. Representative electron microscopy photograph of Schwann cells near a mass of amyloid fibrils. A cross-section of the sural nerve biopsy specimen from a patient with ATTRv amyloidosis. Subunits of Schwann cells indicated by arrowheads are located in the periphery of a mass of amyloid fibrils [28]. A high-powered view in the box is shown in Figure 2. Uranyl acetate and lead citrate stain. Scale bar $=2 \mu \mathrm{m}$. 


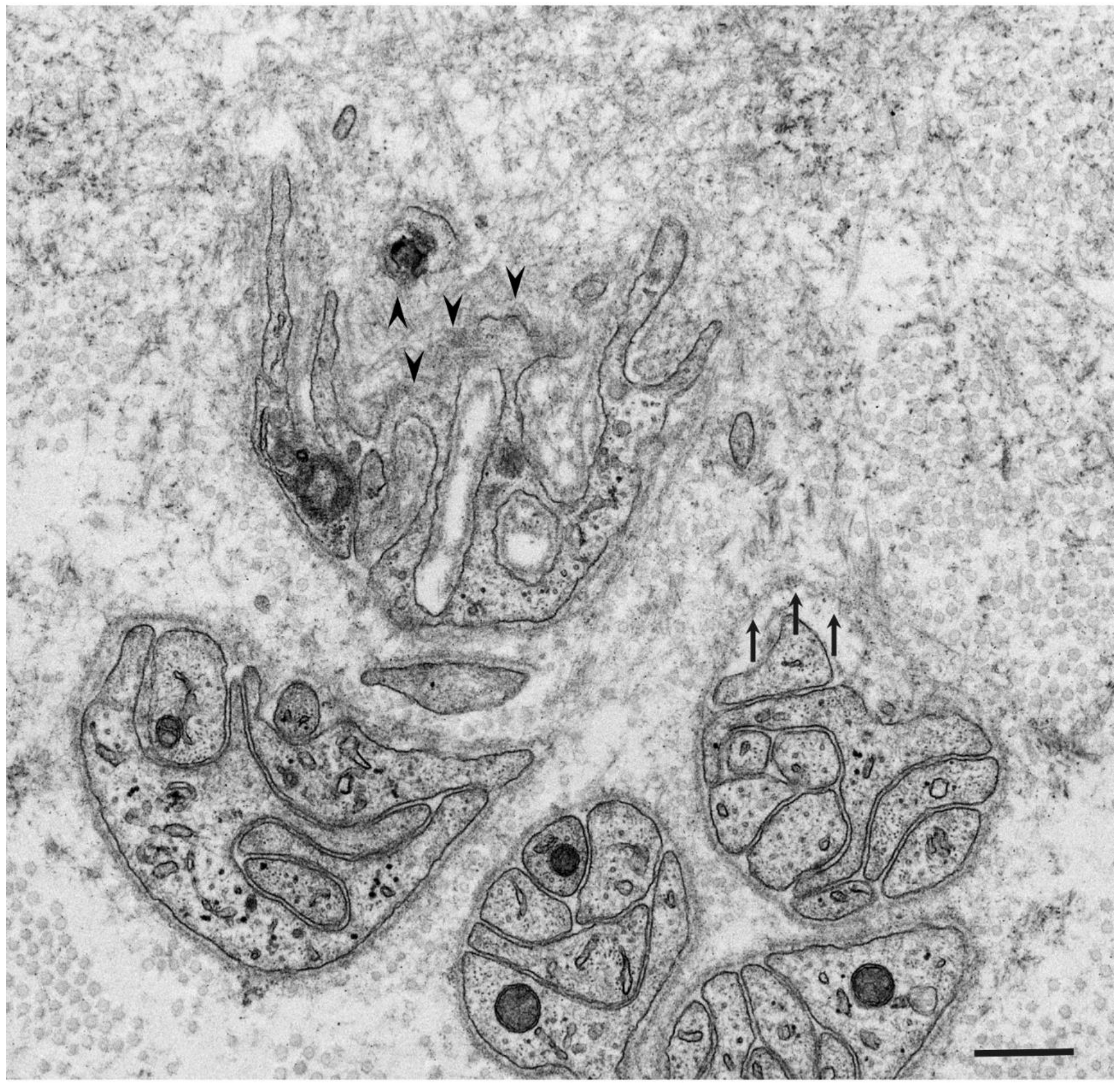

Figure 2. Atrophy of Schwann cells near amyloid fibrils. A cross-section of the sural nerve biopsy specimen from a patient with ATTRv amyloidosis. Basement and cytoplasmic membranes indicated by arrowheads are indistinct [28,29]. A basement membrane indicated by arrows seems to be pulled toward the center of an amyloid fibril mass [29]. Uranyl acetate and lead citrate stain. Scale bar $=0.5 \mu \mathrm{m}$. 


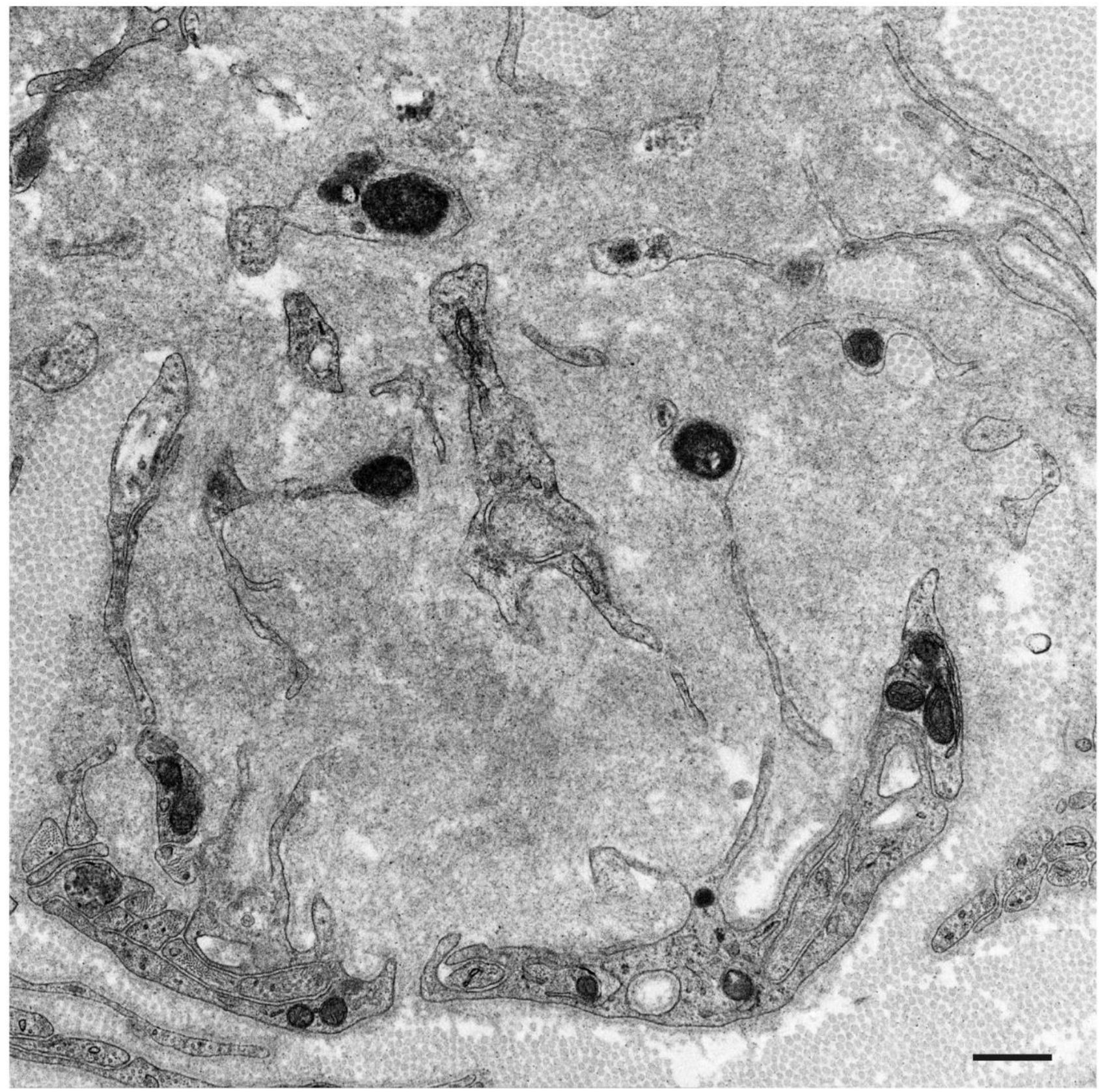

Figure 3. Subunits of Schwann cells surrounded by amyloid fibrils in AL amyloidosis. A cross-section of the sural nerve biopsy specimen. Schwann cells become atrophic and their basement and cytoplasmic membranes are indistinct [21]. Uranyl acetate and lead citrate stain. Scale bar $=0.5 \mu \mathrm{m}$.

\subsection{Obscuration of Basement and Cytoplasmic Membranes}

Another important finding regarding tissue damage resulting from amyloid deposition is the obscuration of the basement and cytoplasmic membranes near amyloid fibrils. Electron microscope studies of nerve biopsy specimens have demonstrated that the membranes of Schwann cells become obscure when they are near amyloid fibrils in both ATTR amyloidosis and AL amyloidosis patients (Figures 2 and 3) [21,28-31]. The contours of Schwann cells may completely disappear when Schwan cells are surrounded by amyloid fibrils, suggesting that the destruction of these membranes occurs as a result of amyloid fibril formation [29]. Scattered cytoplasmic organelles may be found within the aggregates of amyloid fibrils as remnants of Schwann cells in such cases [29]. This destruction of Schwann cell membranes may play an important role in the demyelination reported in 
ATTRv amyloidosis patients [29,42]. Obscuration of basement and cytoplasmic membranes of cells constituting vessel walls, such as endothelial cells and pericytes, near amyloid fibrils has also been demonstrated in ATTRv amyloidosis patients [28].

A previous study of cardiac amyloid deposits suggested that TTR aggregation into fibrillar structures tends to occur in association with the basement membrane because the expression of basement membrane components, such as collagen IV, laminin, and fibronectin, increases in parallel with the accumulation of amyloid fibrils [43]. Studies of nerve biopsy specimens also revealed that amyloid fibrils are frequently found at or around basement membranes surrounding endoneurial microvessels or Schwann cells [6]. These findings suggest an affinity of the components constituting the basement membrane to those of amyloid fibrils. Additionally, a previous study suggested that cholesterol and anionic phospholipids might be important for TTR aggregation and TTR-induced cytotoxicity [44].

\section{Insights into Therapeutic Strategies}

The possible major therapeutic strategies for amyloidosis consist of the following: (1) reducing or preventing the production of causative proteins; (2) preventing the causative proteins from participating in the process of amyloid fibril formation; and/or (3) eliminating the already-deposited amyloid fibrils. As described earlier, the deposition of amyloid fibrils or non-fibrillar oligomers induces atrophy and subsequent degeneration of neighboring cells in amyloidosis. Therefore, intervention during the early stages of the disease process, before the occurrence of tissue damage by amyloid fibrils, seems to be an efficient approach.

From this viewpoint, the development of therapeutic agents to reduce or prevent the production of causative proteins is remarkable in both ATTR and AL amyloidoses. Liver transplantation was established as a treatment for ATTRv amyloidosis in the 1990s to prevent the production of the variant TTR from the liver [45]. Recently, patisiran, a short interfering RNA, and inotersen, an antisense oligonucleotide, were shown to reduce the production of TTR and have become available for ATTRv amyloidosis patients [46,47]. As these gene-silencing agents can prevent the production of both the variant and wild-type TTRs, these drugs are expected to be efficacious even for ATTRwt amyloidosis [48,49]. The main therapeutic strategy for AL amyloidosis is composed of chemotherapy against plasma cell dyscrasia to reduce or prevent the production of immunoglobulin light chains from clonally proliferated plasma cell or B cell lineage [10]. Although a combination of melphalan and steroids is the conventional chemotherapy for treating AL amyloidosis, other agents that are considered include melphalan, thalidomide, lenalidomide, pomalidomide, bortezomib, ixazomib, and daratumumab [10].

As for the strategy of preventing the causative proteins from participating in the process of amyloid fibril formation, TTR stabilizers, such as tafamidis and diflunisal, were demonstrated to be efficacious in patients with ATTR amyloidosis [50,51]. These drugs prevent the dissociation of TTR tetramers, which are physiologically stable, into unstable monomers, thereby inhibiting the subsequent misfolding and aggregation of TTR [6]. Tafamidis, in particular, is now available for not only ATTRv amyloidosis but also ATTRwt amyloidosis patients who have cardiomyopathy $[8,52]$. The use of doxycycline, a derivative of tetracycline that inhibits matrix metalloproteinases dysregulated in tissues in patients with ATTR and AL amyloidoses [53,54], is considered another future add-on option to inhibit amyloid fibril formation [55-57].

Regarding the elimination of amyloid fibrils, monoclonal antibodies against the components of amyloid deposits have been considered therapeutic agent candidates. A humanized IgG1 monoclonal antibody against serum amyloid P component (SAP), which is a plasma glycoprotein found in any type of amyloid deposit, was considered a therapeutic agent for systemic amyloidosis along with the use of an agent that depletes circulating SAP [58]. Although a phase 1 clinical trial demonstrated the shrinkage of amyloid deposits [59], the development of this antibody has been discontinued [18]. Several mon- 
oclonal antibodies specific to TTR or immunoglobulin light chain have also been developed [60-64]. Among these, phase 3 clinical trials of an IgG1 monoclonal antibody against the kappa and lambda light chain amyloid fibrils (CAEL-101) are ongoing (NCT04512235 and NCT04504825) [7].

\section{Conclusions}

Amyloidosis is a group of diseases in which amyloid fibrils are deposited in various organs, including the nervous system, heart, lungs, liver, kidneys, gastrointestinal tract, and soft tissues. Amyloid deposits may be localized to a single organ, as in the case of Alzheimer's disease, or systemic, such as in ATTR and AL amyloidoses.

According to studies of autopsy specimens obtained from patients with ATTRv amyloidosis, the extent of the degeneration of neurons in the sensory and autonomic ganglia is positively correlated with the amount of amyloid, suggesting that neurodegeneration occurs as a result of amyloid deposition $[4,25]$. Electron microscopy examination of nerve biopsy specimens from ATTRv amyloidosis and AL amyloidosis patients demonstrated atrophy of the Schwann cells and loss of associated axons near amyloid fibril aggregates [21,26-31]. Similar findings also were reported in cardiac autopsy specimens from ATTR amyloidosis patients [4]. The mechanisms of atrophy and subsequent degeneration of tissues neighboring amyloid fibrils have not been fully elucidated. In addition to the stress or toxicity attributable to amyloid fibrils themselves, the toxicity of the non-fibrillar states of amyloidogenic proteins may also participate in the mechanisms of tissue damage [9,34-36]. In particular, many studies suggest the importance of non-fibrillar oligomeric species, rather than mature amyloid fibrils, for tissue damage in Alzheimer's disease and prion diseases [34,35].

Another important finding of tissue damage resulting from amyloid deposition is the obscuration of the basement and cytoplasmic membranes of Schwann cells and cells constituting endoneurial microvessels near amyloid fibrils [28,29]. As amyloid fibrils were frequently found at or around basement membranes surrounding endoneurial microvessels or Schwann cells [6], an affinity of components constituting the basement membrane to those of amyloid fibrils may also play an important role in tissue-damage associated with amyloidosis.

The possible major therapeutic strategies for amyloidosis consist of the following: (1) reducing or preventing the production of causative proteins; (2) preventing the causative proteins from participating in the process of amyloid fibril formation; and/or (3) eliminating already-deposited amyloid fibrils. In addition to liver transplantation to prevent the production of variant TTR [45], patisiran, a short interfering RNA, and inotersen, an antisense oligonucleotide, can reduce the production of TTR and have become available for ATTRv amyloidosis patients $[46,47]$. As these gene-silencing agents can prevent the production of both variant and wild-type TTRs, these drugs are also expected to be efficacious even for ATTRwt amyloidosis [48,49]. The main therapeutic strategy for AL amyloidosis is composed of chemotherapy against plasma cell dyscrasia [10]. As for the strategy of preventing the causative proteins from participating in the process of amyloid fibril formation, TTR stabilizers such as tafamidis and diflunisal have been demonstrated to be efficacious in patients with ATTR amyloidosis [50,51]. In particular, tafamidis is now available for not only ATTRv amyloidosis but also for ATTRwt amyloidosis patients who have cardiomyopathy [8,52]. Future therapeutic options include doxycycline as an add-on agent to prevent amyloid fibril formation, and monoclonal antibodies against SAP, TTR, and immunoglobulin light chains to remove the already-deposited amyloid fibrils or their components [18,55-57,60-64]. As the development of these novel disease-modifying therapies is remarkable, early diagnosis and appropriate selection of treatment is becoming more and more important for patients with amyloidosis.

Author Contributions: H.K. conceived and wrote the first draft and M.K. revised it for intellectual content. All authors have read and agreed to the published version of the manuscript. 
Funding: This work was supported by grants from the Ministry of Health, Labor and Welfare (20FC1022) of Japan.

Institutional Review Board Statement: Not applicable.

Informed Consent Statement: Not applicable.

Data Availability Statement: Not applicable.

Conflicts of Interest: The authors declare no conflict of interest.

\section{References}

1. Benson, M.D.; Buxbaum, J.N.; Eisenberg, D.S.; Merlini, G.; Saraiva, M.J.M.; Sekijima, Y.; Sipe, J.D.; Westermark, P. Amyloid nomencla-ture 2020: Update and recommendations by the International Society of Amyloidosis (ISA) nomenclature committee. Amyloid 2020, 27, 217-222. [CrossRef] [PubMed]

2. Hamidi Asl, K.; Liepnieks, J.J.; Nakamura, M.; Benson, M.D. Organ-specific (localized) synthesis of Ig light chain amyloid. J. Immunol. 1999, 162, 5556-5560.

3. Wechalekar, A.D.; Gillmore, J.D.; Hawkins, P.N. Systemic amyloidosis. Lancet 2016, 387, 2641-2654. [CrossRef]

4. Koike, H.; Misu, K.; Sugiura, M.; Iijima, M.; Mori, K.; Yamamoto, M.; Hattori, N.; Mukai, E.; Ando, Y.; Ikeda, S.; et al. Pathology of early- vs late-onset TTR Met30 familial amyloid polyneuropathy. Neurology 2004, 63, 129-138. [CrossRef]

5. Gertz, M.A.; Comenzo, R.; Falk, R.H.; Fermand, J.P.; Hazenberg, B.; Hawkins, P.N.; Merlini, G.; Moreau, P.; Ronco, P.; Sanchorawala, V.; et al. Definition of organ involvement and treatment response in immunoglobulin light chain amyloidosis (AL): A consensus opinion from the 10th International Symposium on Amyloid and Amyloidosis. Am. J. Hematol. 2005, 79, 319-328. [CrossRef] [PubMed]

6. Koike, H.; Katsuno, M. Transthyretin Amyloidosis: Update on the Clinical Spectrum, Pathogenesis, and Disease-Modifying Therapies. Neurol. Ther. 2020, 9, 317-333. [CrossRef] [PubMed]

7. Griffin, J.M.; Rosenblum, H.; Maurer, M.S. Pathophysiology and Therapeutic Approaches to Cardiac Amyloidosis. Circ. Res. 2021, 128, 1554-1575. [CrossRef]

8. Koike, H.; Okumura, T.; Murohara, T.; Katsuno, M. Multidisciplinary Approaches for Transthyretin Amyloidosis. Cardiol. Ther. 2021, in press. [CrossRef]

9. Koike, H.; Katsuno, M. Ultrastructure in Transthyretin Amyloidosis: From Pathophysiology to Therapeutic Insights. Biomedicines 2019, 7, 11. [CrossRef] [PubMed]

10. Gertz, M.A. Immunoglobulin light chain amyloidosis: 2020 update on diagnosis, prognosis, and treatment. Am. J. Hematol. 2020, 95, 848-860. [CrossRef]

11. Koike, H.; Tanaka, F.; Hashimoto, R.; Tomita, M.; Kawagashira, Y.; Iijima, M.; Fujitake, J.; Kawanami, T.; Kato, T.; Yamamoto, M.; et al. Natural history of transthyretin Val30Met familial amyloid polyneuropathy: Analysis of late-onset cases from non-endemic areas. J. Neurol. Neurosurg. Psychiatry 2012, 83, 152-158. [CrossRef]

12. Andrade, C. A peculiar form of peripheral neuropathy; familiar atypical generalized amyloidosis with special involvement of the peripheral nerves. Brain 1952, 75, 408-427. [CrossRef] [PubMed]

13. Araki, S.; Mawatari, S.; Ohta, M.; Nakajima, A.; Kuroiwa, Y. Polyneuritic Amyloidosis in a Japanese Family. Arch. Neurol. 1968, 18, 593-602. [CrossRef] [PubMed]

14. Andersson, R. Familial amyloidosis with polyneuropathy. A clinical study based on patients living in northern Sweden. Acta Medica Scand. Suppl. 1976, 590, 1-64.

15. Cornwell, G.G., III; Murdoch, W.L.; Kyle, R.A.; Westermark, P.; Pitkänen, P. Frequency and distribution of senile cardiovascular amyloid. A clinicopathologic correlation. Am. J. Med. 1983, 75, 618-623. [CrossRef]

16. Ueda, M.; Horibata, Y.; Shono, M.; Misumi, Y.; Oshima, T.; Su, Y.; Tasaki, M.; Shinriki, S.; Kawahara, S.; Jono, H.; et al. Clinicopathological features of senile systemic amyloidosis: An ante- and post-mortem study. Mod. Pathol. 2011, 24, 1533-1544. [CrossRef] [PubMed]

17. Sekijima, Y.; Yazaki, M.; Ueda, M.; Koike, H.; Yamada, M.; Ando, Y. First nationwide survey on systemic wild-type ATTR amy-loidosis in Japan. Amyloid 2018, 25, 8-10. [CrossRef] [PubMed]

18. Adams, D.; Koike, H.; Slama, M.; Coelho, T. Hereditary transthyretin amyloidosis: A model of medical progress for a fatal disease. Nat. Rev. Neurol. 2019, 15, 387-404. [CrossRef]

19. Kyle, R.A.; Greipp, P.R. Amyloidosis (AL). Clinical and laboratory features in 229 cases. Mayo. Clin. Proc. 1983, 58, 665-683.

20. Koike, H.; Misu, K.; Ikeda, S.; Ando, Y.; Nakazato, M.; Ando, E.; Yamamoto, M.; Hattori, N.; Sobue, G. Study Group for Hereditary Neuropathy in Japan. Type I (transthyretin Met30) familial amyloid polyneuropathy in Japan: Early- vs late-onset form. Arch. Neurol. 2002, 59, 1771-1776. [CrossRef] [PubMed]

21. Koike, H.; Mouri, N.; Fukami, Y.; Iijima, M.; Matsuo, K.; Yagi, N.; Saito, A.; Nakamura, H.; Takahashi, K.; Nakae, Y.; et al. Two distinct mechanisms of neuropathy in immunoglobulin light chain (AL) amyloidosis. J. Neurol. Sci. 2021, 421, 117305. [CrossRef]

22. Koike, H.; Hashimoto, R.; Tomita, M.; Kawagashira, Y.; Iijima, M.; Tanaka, F.; Sobue, G. Diagnosis of sporadic transthyretin Val30Met familial amyloid polyneuropathy: A practical analysis. Amyloid 2011, 18, 53-62. [CrossRef] 
23. González-López, E.; Gallego-Delgado, M.; Guzzo-Merello, G.; Moral, F.J.D.H.-D.; Cobo-Marcos, M.; Robles, C.; Bornstein, B.; Salas, C.; Lara-Pezzi, E.; Alonso-Pulpon, L.; et al. Wild-type transthyretin amyloidosis as a cause of heart failure with preserved ejection fraction. Eur. Heart J. 2015, 36, 2585-2594. [CrossRef] [PubMed]

24. Griffin, J.M.; Maurer, M.S. Transthyretin cardiac amyloidosis: A treatable form of heart failure with a preserved ejection frac-tion. Trends Cardiovasc. Med. 2021, 31, 59-66. [CrossRef] [PubMed]

25. Sobue, G.; Nakao, N.; Murakami, K.; Yasuda, T.; Sahashi, K.; Mitsuma, T.; Sasaki, H.; Sakaki, Y.; Takahashi, A. Type I familial amyloid polyneuropathy. A pathological study of the peripheral nervous system. Brain 1990, 113, 903-919. [CrossRef] [PubMed]

26. Coimbra, A.; Andrade, C. Familial amyloid polyneuropathy: An electron microscope study of the peripheral nerve in five cases. I. interstitial changes. Brain 1971, 94, 199-206. [CrossRef] [PubMed]

27. Thomas, P.K.; King, R.H. Peripheral nerve changes in amyloid neuropathy. Brain 1974, 97, 395-406. [CrossRef]

28. Koike, H.; Ikeda, S.; Takahashi, M.; Kawagashira, Y.; Iijima, M.; Misumi, Y.; Ando, Y.; Ikeda, S.-I.; Katsuno, M.; Sobue, G. Schwann cell and endothelial cell damage in transthyretin familial amyloid polyneuropathy. Neurology 2016, 87, 2220-2229. [CrossRef]

29. Koike, H.; Nishi, R.; Ikeda, S.; Kawagashira, Y.; Iijima, M.; Sakurai, T.; Shimohata, T.; Katsuno, M.; Sobue, G. The morphology of am-yloid fibrils and their impact on tissue damage in hereditary transthyretin amyloidosis: An ultrastructural study. J. Neurol. Sci. 2018, 394, 99-106. [CrossRef]

30. Vital, C.; Vallat, J.M.; Deminiere, C.; Loubet, A.; Leboutet, M.J. Peripheral nerve damage during multiple myeloma and Waldenstrom's macroglobulinemia: An ultrastructural and immunopathologic study. Cancer 1982, 50, 1491-1497. [CrossRef]

31. Sommer, C.; Schröder, J.M. Amyloid neuropathy: Immunocytochemical localization of intra- and extracellular immuno-globulin light chains. Acta. Neuropathol. 1989, 79, 190-199. [CrossRef] [PubMed]

32. Koike, H.; Ando, Y.; Ueda, M.; Kawagashira, Y.; Iijima, M.; Fujitake, J.; Hayashi, M.; Yamamoto, M.; Mukai, E.; Nakamura, T.; et al. Distinct characteristics of amyloid deposits in early- and late-onset transthyretin Val30Met familial amyloid polyneuropathy. J. Neurol. Sci. 2009, 287, 178-184. [CrossRef]

33. Koike, H.; Fukami, Y.; Nishi, R.; Kawagashira, Y.; Iijima, M.; Sobue, G.; Katsuno, M. Clinicopathological spectrum and recent ad-vances in the treatment of hereditary transthyretin amyloidosis. Neurol. Clin. Neurosci. 2019, 7, 166-173. [CrossRef]

34. Aguzzi, A.; O'Connor, T. Protein aggregation diseases: Pathogenicity and therapeutic perspectives. Nat. Rev. Drug Discov. 2010, 9 , 237-248. [CrossRef] [PubMed]

35. Knowles, T.; Vendruscolo, M.; Dobson, C.M. The amyloid state and its association with protein misfolding diseases. Nat. Rev. Mol. Cell Biol. 2014, 15, 384-396. [CrossRef]

36. Obici, L.; Adams, D. Acquired and inherited amyloidosis: Knowledge driving patients' care. J. Peripher. Nerv. Syst. 2020, 25, 85-101. [CrossRef]

37. Sousa, M.M.; Cardoso, I.; Fernandes, R.; Guimarães, A.; Saraiva, M.J. Deposition of transthyretin in early stages of familial amy-loidotic polyneuropathy: Evidence for toxicity of nonfibrillar aggregates. Am. J. Pathol. 2001, 159, 1993-2000. [CrossRef]

38. Monteiro, F.A.; Sousa, M.M.; Cardoso, I.; do Amaral, J.B.; Guimarães, A.; Saraiva, M.J. Activation of ERK1/2 MAP kinases in familial amyloidotic polyneuropathy. J. Neurochem. 2006, 97, 151-161. [CrossRef]

39. Fong, V.H.; Vieira, A. Pro-oxidative effects of aggregated transthyretin in human Schwannoma cells. NeuroToxicology 2013, 39, 109-113. [CrossRef]

40. Ibrahim, R.B.; Yeh, S.Y.; Lin, K.P.; Ricardo, F.; Yu, T.Y.; Chan, C.C.; Tsai, J.W.; Liu, Y.T. Cellular Secretion and Cytotoxicity of Transthy-retin Mutant Proteins Underlie Late-Onset Amyloidosis and Neurodegeneration. Cell Mol. Life Sci. 2020, 77, 1421-1434. [CrossRef] [PubMed]

41. Madhivanan, K.; Greiner, E.R.; Alves-Ferreira, M.; Soriano-Castell, D.; Rouzbeh, N.; Aguirre, C.A.; Paulsson, J.F.; Chapman, J.; Jiang, X.; Ooi, F.K.; et al. Cellular clearance of circulating transthyretin decreases cell-nonautonomous proteotoxicity in Caenorhabditis elegans. Proc. Natl. Acad. Sci. USA 2018, 115, E7710-E7719. [CrossRef] [PubMed]

42. Said, G.; Ropert, A.; Faux, N. Length-dependent degeneration of fibers in Portuguese amyloid polyneuropathy: A clinicopathologic study. Neurology 1984, 34, 1025-1032. [CrossRef] [PubMed]

43. Misumi, Y.; Ando, Y.; Ueda, M.; Obayashi, K.; Jono, H.; Su, Y.; Yamashita, T.; Uchino, M. Chain reaction of amyloid fibril formation with induction of basement membrane in familial amyloidotic polyneuropathy. J. Pathol. 2009, 219, 481-490. [CrossRef]

44. Hou, X.; Mechler, A.; Martin, L.L.; Aguilar, M.I.; Small, D.H. Cholesterol and anionic phospholipids increase the binding of amy-loidogenic transthyretin to lipid membranes. Biochim. Biophys. Acta 2008, 1778, 198-205. [CrossRef]

45. Holmgren, G.; Steen, L.; Ekstedt, J.; Groth, C.-G.; Ericzon, B.-G.; Eriksson, S.; Andersen, O.; Karlberg, I.; Nordén, G.; Nakazato, M.; et al. Biochemical effect of liver transplantation in two Swedish patients with familial amyloidotic polyneuropathy (FAP-met30). Clin. Genet. 1991, 40, 242-246. [CrossRef] [PubMed]

46. Adams, D.; Gonzalez-Duarte, A.; O’Riordan, W.D.; Yang, C.C.; Ueda, M.; Kristen, A.V.; Tournev, I.; Schmidt, H.H.; Coelho, T.; Berk, J.L.; et al. Patisiran, an RNAi Therapeutic, for Hereditary Transthyretin Amyloidosis. N. Engl. J. Med. 2018, 379, 11-21. [CrossRef]

47. Benson, M.D.; Waddington-Cruz, M.; Berk, J.L.; Polydefkis, M.; Dyck, P.J.; Wang, A.K.; Planté-Bordeneuve, V.; Barroso, F.A.; Merlini, G.; Obici, L.; et al. Inotersen Treatment for Patients with Hereditary Transthy-retin Amyloidosis. N. Engl. J. Med. 2018, 379, 22-31. [CrossRef]

48. Emdin, M.; Aimo, A.; Rapezzi, C.; Fontana, M.; Perfetto, F.; Seferović, P.M.; Barison, A.; Castiglione, V.; Vergaro, G.; Giannoni, A.; et al. Treatment of cardiac transthyretin amyloidosis: An update. Eur. Hear. J. 2019, 40, 3699-3706. [CrossRef] [PubMed] 
49. Dasgupta, N.R.; Rissing, S.M.; Smith, J.; Jung, J.; Benson, M.D. Inotersen therapy of transthyretin amyloid cardiomyopathy. Amyloid 2019, 27, 52-58. [CrossRef] [PubMed]

50. Coelho, T.; Maia, L.; da Silva, A.M.; Cruz, M.W.; Planté-Bordeneuve, V.; Lozeron, P.; Suhr, O.; Campistol, J.M.; Conceicao, I.; Schmidt, H.H.-J.; et al. Tafamidis for transthyretin familial amyloid polyneuropathy: A randomized, controlled trial. Neurology 2012, 79, 785-792. [CrossRef] [PubMed]

51. Berk, J.L.; Suhr, O.B.; Obici, L.; Sekijima, Y.; Zeldenrust, S.R.; Yamashita, T.; Heneghan, M.A.; Gorevic, P.D.; Litchy, W.J.; Wiesman, J.F.; et al. Diflunisal Trial Consortium. Repurposing diflunisal for familial amyloid poly-neuropathy: A randomized clinical trial. JAMA 2013, 310, 2658-2667. [CrossRef] [PubMed]

52. Maurer, M.S.; Schwartz, J.H.; Gundapaneni, B.; Elliott, P.M.; Merlini, G.; Waddington-Cruz, M.; Kristen, A.V.; Grogan, M.; Witteles, R.; Damy, T.; et al. Tafamidis Treatment for Patients with Transthyretin Amyloid Car-diomyopathy. N. Engl. J. Med. 2018, 379, 1007-1016. [CrossRef] [PubMed]

53. Sousa, M.; Amaral, J.; Guimarães, A.; Saraiva, M.J. Up-regulation of the extracellular matrix remodeling genes, biglycan, neutrophil gelatinase-associated lipocalin and matrix metalloproteinase-9 in familial amyloid polyneuropathy. FASEB J. 2004, 19, 124-126. [CrossRef]

54. Biolo, A.; Ramamurthy, S.; Connors, L.H.; O’Hara, C.J.; Meier-Ewert, H.K.; Soo Hoo, P.T.; Sawyer, D.B.; Seldin, D.C.; Sam, F. Matrix met-alloproteinases and their tissue inhibitors in cardiac amyloidosis: Relationship to structural, functional myocardial changes and to light chain amyloid deposition. Circ. Heart Fail. 2008, 1, 249-257. [CrossRef]

55. Obici, L.; Cortese, A.; Lozza, A.; Lucchetti, J.; Gobbi, M.; Palladini, G.; Perlini, S.; Saraiva, M.J.; Merlini, G. Doxycycline plus taurour-sodeoxycholic acid for transthyretin amyloidosis: A phase II study. Amyloid 2012, 19 (Suppl. 1), 34-36. [CrossRef] [PubMed]

56. Karlstedt, E.; Jimenez-Zepeda, V.; Howlett, J.G.; White, J.A.; Fine, N.M. Clinical Experience with the Use of Doxycycline and Ur-sodeoxycholic Acid for the Treatment of Transthyretin Cardiac Amyloidosis. J. Card Fail. 2019, 25, 147-153. [CrossRef] [PubMed]

57. D'Souza, A.; Szabo, A.; Flynn, K.E.; Dhakal, B.; Chhabra, S.; Pasquini, M.C.; Weihrauch, D.; Hari, P.N. Adjuvant doxycycline to en-hance anti-amyloid effects: Results from the dual phase 2 trial. EClinicalMedicine 2020, 23, 100361. [CrossRef]

58. Bodin, K.; Ellmerich, S.; Kahan, M.C.; Tennent, G.A.; Loesch, A.; Gilbertson, J.A.; Hutchinson, W.L.; Mangione, P.P.; Gallimore, J.R.; Millar, D.J.; et al. Antibodies to human serum amyloid P component eliminate visceral amyloid deposits. Nature 2010, 468, 93-97. [CrossRef] [PubMed]

59. Richards, D.; Cookson, L.M.; Berges, A.C.; Barton, S.V.; Lane, T.; Ritter, J.M.; Fontana, M.; Moon, J.; Pinzani, M.; Gillmore, J.D.; et al. Therapeutic Clearance of Amyloid by Antibodies to Serum Amyloid P Component. N. Engl. J. Med. 2015, 373, 1106-1114. [CrossRef]

60. Wall, J.S.; Kennel, S.J.; Stuckey, A.C.; Long, M.J.; Townsend, D.W.; Smith, G.T.; Wells, K.J.; Fu, Y.; Stabin, M.G.; Weiss, D.T.; et al. Ra-dioimmunodetection of amyloid deposits in patients with AL amyloidosis. Blood 2010, 116, 2241-2244. [CrossRef]

61. Gertz, M.A.; Landau, H.; Comenzo, R.L.; Seldin, D.; Weiss, B.; Zonder, J.; Merlini, G.; Schönland, S.; Walling, J.; Kinney, G.G.; et al. First-in-Human Phase I/II Study of NEOD001 in Patients with Light Chain Amyloidosis and Persistent Organ Dysfunction. J. Clin. Oncol. 2016, 34, 1097-1103. [CrossRef]

62. Hosoi, A.; Su, Y.; Torikai, M.; Jono, H.; Ishikawa, D.; Soejima, K.; Higuchi, H.; Guo, J.; Ueda, M.; Suenaga, G.; et al. Novel Antibody for the Treatment of Transthyretin Amyloidosis. J. Biol. Chem. 2016, 291, 25096-25105. [CrossRef] [PubMed]

63. George, J.; Rappaport, M.; Shimoni, S.; Goland, S.; Voldarsky, I.; Fabricant, Y.; Edri, O.; Cuciuc, V.; Lifshitz, S.; Tshori, S.; et al. novel monoclonal antibody targeting aggregated transthyretin facilitates its removal and functional recovery in an exper-imental model. Eur. Heart J. 2020, 41, 1260-1270. [CrossRef] [PubMed]

64. Michalon, A.; Hagenbuch, A.; Huy, C.; Varela, E.; Combaluzier, B.; Damy, T.; Suhr, O.B.; Saraiva, M.J.; Hock, C.; Nitsch, R.M.; et al. A human antibody selective for transthyretin amyloid removes cardiac amyloid through phagocytic immune cells. Nat. Commun. 2021, 12, 3142. [CrossRef] [PubMed] 